\title{
PENINGKATAN KEPATUHAN POLA HIDUP MELALUI PENYULUHAN KESEHATAN PADA KLIEN HIPERTENSI
}

\author{
Lisbeth Pardede ${ }^{1}$, Renta Sianturi ${ }^{2}$, Aprillia Veranita ${ }^{3}$ \\ ${ }^{1,3}$ Departemen keperawatan Medikal bedah STIKes Mitra Keluarga \\ ${ }^{2}$ Departemen keperawatan Jiwa STIKes Mitra Keluarga \\ Email: lisbethbb67@gmail.com
}

\begin{abstract}
Abstrak
Hipertensi merupakan suatu penyakit kronik, berulang dan angka kejadiannya semakin meningkat setiap tahun. Penanganan hipertensi membutuhkan waktu seumur hidup, serta membutuhkan kepatuhan klien dalam menjaga pola hidup. Namun banyak klien hipertensi tidak mampu menjaga pola hidupnya sehingga perlu dilakukan cara untuk meningkatkan kepatuhan klien dalam menjaga pola hidup. Penelitian ini dilakukan dengan quasi eksperiment, jumlah responden 66 orang dipilih dengan purposive sampling, desain pre post test. Data yang dikumpulkan yaitu karakteristik responden, kepatuhan pola hidup meliputi kepatuhan makan dan minum, kepatuhan aktivitas dan istirahat, pengendalian stress dan kepatuhan kontrol dan minum obat. Hasil penelitian yaitu ada perbedaan nilai rata - rata sebelum dan sesudah dilakukan penyuluhan kesehatan p value $(0,000)$ dengan CI 95\%. Setelah diberikan penyuluhan terjadi peningkatan pengetahuan responden yang berdampak pada perubahan sikap dan perilaku dalam menjaga pola hidup. Oleh karena itu penyuluhan kesehatan perlu ditingkatkan dilayanan kesehatan primer sebagai salah satu bentuk intervensi penanganan hipertensi.
\end{abstract}

Kata Kunci: Hipertensi, Kepatuhan, Penyuluhan Kesehatan, Pola Hidup

\begin{abstract}
Abstrack
Hypertension is a chronic disease, recurring and the incidence rate is increasing annually. Hypertension required long-term handling and demanding patient awareness in the maintenance of healthy behaviours. Indeed, a large number of a patient unable to maintaining their behaviours so that needed in any way to the improvement of patient behaviours within the upkeep of their lifestyles. The research was undertaken with a quasi-experiment and be selected are 66 people by purposive-sampling and design of the pre-post test. The data collected were according to the characteristic of respondents, lifestyles obedience in consist of obedience of consumption, physical activity, rest, management of stress, controlling, and medicine intake as well. The result was any diversity of mean between before and after health education were p-value (0,000) with 95\% CI. The after providing health education come about an increase in respondent knowledge which one influenced in either of attitude changes and conduct within the lifestyles. Therefore, in primary health care highly needed the health education improvement as one of the interventions client with hypertension.
\end{abstract}

Keywords: hypertension, Obedience, Health Education, Lifestyle

\section{Pendahuluan}

Hipertensi merupakan penyakit kronik yang cenderung meningkat pada masyarakat. Data World Health Organization (WHO) tahun 2011 menunjukkan satu milyar orang di dunia menderita Hipertensi, 2/3 diantaranya berada di negara berkembang yang berpenghasilan rendah sampai sedang. Prevalensi Hipertensi akan terus meningkat tajam dan diprediksi pada tahun 2025 sebanyak $29 \%$ orang dewasa di seluruh 
dunia terkena Hipertensi. Hipertensi telah mengakibatkan kematian sekitar 8 juta orang setiap tahun, dimana 1,5 juta kematian terjadi di Asia Tenggara yang 1/3 populasinya menderita hipertensi (WHO, 2011). Prevalensi Hipertensi nasional berdasarkan Riskesdas 2013 sebesar 25,8\%, tertinggi di kepulauan Bangka Belitung (30,9\%), sedangkan terendah di Papua sebesar $(16,8 \%)$. Berdasarkan data tersebut dari $25,8 \%$ orang yang mengalami hipertensi hanya $1 / 3$ yang terdiagnosis, sisanya $2 / 3$ tidak terdiagnosis. Data menunjukkan hanya $0,7 \%$ orang yang terdiagnosis tekanan darah tinggi minum obat Hipertensi (Riskesdas, 2018).

Hipertensi yang tidak mendapat penanganan yang baik menyebabkan komplikasi seperti Stroke, Penyakit Jantung Koroner, Diabetes, Gagal Ginjal dan Kebutaan. Stroke (51\%) dan Penyakit Jantung Koroner (45\%) merupakan penyebab kematian tertinggi.. Penyebab terjadinya komplikasi pada klien hipertensi diakibatkan tidak dapat menjaga pola hidup seperti menjaga pola makan, manajemen berat badan, aktivitas fisik yang sesuai, kepatuhan minum obat (Fodor, G. F., et al., 2009; Tshitenge, \& Mabuza, 2015;
Khayyat, H, et. al., 2017; Myung, H.Y., et.al., 2017).

Data yang didapatkan dari hasil penelitian bahwa sebanyak $37 \%$ klien hipertensi di pakistan tidak patuh menjaga pola hidup (Al-Saadi, R. et.al., 2011), sementara di Indonesia di RSUP Fatmawati sebanyak 63,8\% dari 80 klien hipertensi mengalami ketidakpatuhan menjaga pola hidup (Indriawaty \& Usman,S, 2018), di negara ASEAN diketahui bahwa 79,2\% tidak patuh terhadap pola hidup (Kumara, N., et.al.,2013).

Penelitian ditemukan bahwa faktor yang signifikan mempengaruhi ketidakpatuhan menjaga pola hidup pada klien hipertensi yaitu pengetahuan (Pratama \&Ariastuti, 2016). Pujasari, et al. (2017) menyatakan bahwa faktor kurangnya pengetahuan pada klien hipertensi lebih mempengaruhi ketidak patuhan pola hidup dibandingkan lamanya pengobatan.

Peningkatan pengetahuan dapat dilakukan dengan cara penyuluhan kesehatan. Lubis, et al. (2013) menyatakan bahwa penyuluhan kesehatan dengan metode ceramah dan diskusi dapat meningkatkan pengetahuan 
responden. Kapti,et al. (2013) menyatakan bahwa penyuluhan efektif dalam meningkatkan pengetahuan serta merubah perilaku dan sikap ibu dalam tatalaksana balita dengan diare. Berdasarkan hasil penelitian tersebut peneliti memilih penyuluhan kesehatan sebagai salah satu intervensi untuk meningkatkan pengetahuan tentang pola hidup hipertensi yang akan berdampak pada sikap dan perilaku klien hipertensi.

\section{Metode}

Penelitian ini merupakan penelitian kuantitatif menggunakan metode quasy experimental dengan rancangan pre post test. Jumlah responden yang terlibat dalam penelitian sebanyak 66 orang dengan kriteria inklusi: klien dengan hipertensi, dapat membaca dan menulis dan bersedia sebagai responden. Pemilihan responden dilakukan dengan purposive sampling (Kusuma, 2016). Instrument yang digunakan dalam penelitian ini adalah instrument yang menggambarkan tentang karakteristik responden dan pola hidup yaitu pola makan dan minum, aktivitas dan istirahat, pengendalian stress, kontrol tekanan darah dan minum obat. Instrument telah dilakukan uji validitas dan reabilitas dengan hasil instrument valid dan realeable (Luknis, 2014). Penelitian dilakukan di salah satu Puskesmas Kecamatan di daerah Bekasi Jawa Barat.

Penelitian ini sudah dilakukan terlebih dahulu uji etik dengan hasil bahwa penelitian ini tidak menjadi hazard bagi responden dan dapat dilakukan di tempat penelitian.

Penelitian ini diberikan intervensi penyuluhan kesehatan. Pada tahap awal responden akan diberikan penjelasan penelitian, kemudian responden menanda tangani inform consent dilanjutkan dengan pemberian penyuluhan kesehatan. Penyuluhan kesehatan diberikan secara individu dengan ceramah, audiovisual dan diskusi sampai akhirnya responden dilakukan evaluasi tentang materi yang disampaikan. Responden harus memahami sebesar $80 \%$ dari materi. Setelah responden memahami materi diberikan kesempatan untuk merubah pola hidup sesuai dengan pengetahuan yang sudah didapatkan selama 2 bulan. Setelah 2 bulan responden dilakukan post test dengan cara mengisi kuesioner kepatuhan pola hidup dan pengukuran tekanan darah. 
Hasil post test akan dibandingkan dengan hasil pre test untuk melihat keefektifan penyuluhan kesehatan yang telah diberikan kepada responden. Hasil pre dan post test akan diolah dengan editing, coding dan tabulasi data. Setelah data ditabulasi maka data dianalisa dengan menggunakan program komputer.

\section{Hasil}

Tabel 1 menjelaskan tentang karakteristik responden berdasarkan usia, lama menderita hipertensi dan IMT. Rerata usia 53 tahun, lama menderita hipertensi 7 tahun dan rerata IMT sebesar 28,89 yang termasuk kedalam kelompok obesitas.

\section{Tabel 1 : Karakteristik Responden Berdasarkan Usia, Lama Menderita Hipertensi dan IMT}

\begin{tabular}{cccc}
\hline Variabel & Mean & Min-Max & SD \\
\hline Usia & 53,03 & $18-65$ & 10,02 \\
\hline $\begin{array}{c}\text { Lama menderita } \\
\text { Hipertensi }\end{array}$ & 7,33 & $1-25$ & 7,33 \\
\hline IMT & 28,89 & $18-40$ & 5,067 \\
\hline
\end{tabular}

Tabel 2 menjelaskan tentang karakteristik responden berdasarkan jenis kelamin dan pendidikan. Jenis kelamin responden mayoritas perempuan $(78,8 \%)$ dan tingkat pendidikan mayoritas lulusan SD (42,2\%).
Tabel 2: Karakteristik Responden Berdasarkan Jenis Kelamin Dan Pendidikan

\begin{tabular}{ccc}
\hline Variabel & Kategori & Frekuensi \\
\hline \multirow{2}{*}{ Jenis Kelamin } & Laki - Laki & $21,2 \%$ \\
\cline { 2 - 3 } & Perempuan & $78,8 \%$ \\
\hline \multirow{3}{*}{ Pendidikan } & SD & $42,2 \%$ \\
\cline { 2 - 3 } & SMP & $15,2 \%$ \\
\cline { 2 - 3 } & SMA & $36,4 \%$ \\
\cline { 2 - 3 } & SARJANA & $6,1 \%$ \\
\cline { 2 - 3 } & SD & 18,2 \\
\cline { 2 - 3 } & SMP & $9,1 \%$ \\
\cline { 2 - 3 } & SMA & $60,6 \%$ \\
\cline { 2 - 3 } & SARJANA & $12,1 \%$ \\
\hline
\end{tabular}

Tabel 3: Kepatuhan Pola Hidup Klien Hipertensi

\begin{tabular}{|c|c|c|c|c|c|c|c|}
\hline \multicolumn{2}{|c|}{ Variabel } & \multicolumn{2}{|c|}{ Mean Selisih } & \multirow{2}{*}{$\begin{array}{l}\text { SD } \\
14,29\end{array}$} & \multirow{2}{*}{$\frac{\mathbf{S E}}{2,49}$} & \multirow{2}{*}{$\begin{array}{c}T \\
6,20\end{array}$} & \multirow{2}{*}{$\begin{array}{c}\begin{array}{c}P \\
\text { Value }\end{array} \\
\mathbf{0 . 0 0 0}\end{array}$} \\
\hline Kepat & Pre & 71,33 & \multirow[b]{2}{*}{5,03} & & & & \\
\hline $\begin{array}{l}\text { Pola } \\
\text { Hidup }\end{array}$ & Post & 66,30 & & 12,98 & 2,26 & 6,20 & $\mathbf{0 , 0 0 0}$ \\
\hline
\end{tabular}

Tabel 3 menjelaskan tentang kepatuhan pola hidup klien hipertensi. Penyuluhan kesehatan memiliki pengaruh terhadap perubahan nilai mean 5,03 pada kepatuhan pola hidup pada klien hipertensi di Puskesmas. Secara statistik didapatkan nilai $\mathrm{t}=6,20$ dan $p$ value 0,000 lebih kecil dari 0,05, hal ini berarti pengaruh promosi kesehatan significan terhadap kepatuhan pola hidup $($ pvalue $=0,000 ;$ Ho ditolak $)$. Hasil penelitian menunjukkan bahwa ada perbedaan rata - rata nilai kepatuhan responden sebelum dan sesudah diberikan penyuluhan kesehatan. 


\section{Pembahasan}

Kategori usia responden pada penelitian berada pada kategori lansia awal dan lansia akhir (Muamala, 2018), responden rentan mengalami peningkatan tekanan darah, akibat adanya aging process pada usia tersebut. Aging process memiliki dampak terhadap perubahan kontraktilitas jantung dan elastisitas pembuluh darah. Perubahan tersebut menyebabkan perlu tekanan yang lebih tinggi untuk memompakan darah keseluruh tubuh dan darah balik kejantung. Hasil penelitian didapatkan bahwa usia memiliki hubungan signifikan terhadap terjadinya hipertensi, semakin bertambah usia maka akan terjadi peningkatan tekanan darah sebesar 80\% (Widjaya, et.al., 2018; Wahyuningsih, Muttia Amalia \& nurfitri Bustaman, 2017).

Rerata lama mengalami hipertensi dalam waktu 7 tahun yang berarti bahwa responden mengalami hipertensi kronik. Hipertensi kronik disebabkan kurangnya kepatuhan pola hidup responden serta kurangnya pengetahuan responden sehingga tidak mampu mepertahankan penanganan yang rutin dalam jangka waktu yang lama. Klien dengan hipertensi jangka panjang akan menimbulkan komplikasi yang lebih buruk dan semakin susah untuk ditangani (Laksita, 2016).

Indeks Masa tubuh responden berada pada penggolongan obesitas. IMT merupakan indicator yang dapat digunakan sebagai acuan untuk mengukur lemak tubuh. Pengukuran IMT dinilai murah dan mudah untuk melakukan skrining dalam mengkategorikan BB yang menjurus kepada masalah kesehatan. IMT berhubungan dengan terjadinya hipertensi pada GGK (Sucitaningtyas, 2017).

Leptin, asam lemak bebas dan insulin serta obstructive sleep apnea yang meningkat pada obes akan menyebabkan konstriksi dan aktifitas sistem saraf simpatis. Resistensi insulin dan disfungsional endotelia juga menyebabkan vasokonstriksi. Peningkatan aktifitas saraf simpatis, ginjal, resistensi insulin dan hiperaktifitas sistem renin angiotensin menjadikan reabsorbsi natrium pada ginjal meninggi. Faktor-faktor tersebut akan mengakibatkan terjadinya hipertensi (Batara, Bodhi, \& Kepel, 2016).

Marlina dkk. (2016) menyatakan dalam penelitiannya bahwa terdapat korelasi positif antara IMT/U dengan tekanan sistolik dan 
diastolik, yaitu setiap kenaikan $1 \mathrm{~kg} / \mathrm{m} 2$ IMT/U akan diikuti dengan kenaikan tekanan sistolik dan diastolik masing-masing 2,339 $\mathrm{mmHg}$ dan $0,979 \mathrm{mmHg}$ (Marlina, et.al., 2016).

Hasil penelitian menunjukkan bahwa tidak ada hubugan antara jenis kelamin dengan kejadian hipertensi (Sari, 2016). Sementara hasil penelitian Novitaningtyas (2014) mengatakan bahwa jenis kelamin dengan tingkat pendidikan tidak mempengaruhi kejadian hipertensi pada dewasa muda sampai lansia. Sementara aktifitas fisik sangat memiliki hubungan dengan kejadian hipertensi. Hasil penelitian Sofyan mengatakan bahwa jenis kelamin tidak memiliki hubungan dengan kejadian hipertensi hanya dipengaruhi oleh usia (Sofyan, Ika Yulieta \& Yususf Hamra. 2015).

Berdasarkan penelitian jenis kelamin perempuan lebih banyak daripada jenis kelamin laki-laki. Perempuan lebih berisiko untuk terkena Hipertensi dibandingkan dengan laki -laki, sebelum menopause wanita cenderung terlindungi oleh hormon estrogen yang dimana kadar estrogen menurun setelah menopause. Pada wanita seringkali dipicu oleh perilaku tidak sehat (konsumsi makanan dalam jumlah berlebihan, kelebihan berat badan/overweight), depresi, dan status pekerjaan yang menyebabkan kurang gerak (Arief, 2008)

Tingkat pendidikan memiliki pengaruh yang besar terhadap kejadian hipertensi sebesar $69 \%$. Hal ini disebabkan oleh adanya proses pendewasaan dalam mengambil keputusan, kemampuan untuk menangkap informasi serta memiliki kemampuan mengambil keputusan sesuai informasi yang didapatkan (Aryanto, 2018). Rerata tingkat pendidikan responden adalah SMA.

Tingkat pendidikan seseorang mempengaruhi pengetahuan. Pendidikan merupakan suatu kegiatan sadar tujuan, yaitu kegiatan secara sistematika terarah pada perubahan tingkah laku menuju tercapainya tujuan yang diinginkan. Pendidikan adalah proses perubahan sikap dan perilaku seseorang atau sekelompok orang dalam usaha mendewasakan manusia melalui upaya pelatihan dan pengajaran, proses, perbuatan dan cara mendidik (Ngatimin, 2003). 
Hasil penelitian menunjukkan bahwa masih banyak responden penelitian yang berpendidikan SD. Rendahnya tingkat pendidikan maka akan diikuti oleh penurunan derajat kesehatan seseorang, dikarenakan pengetahuan yang cukup untuk seseorang melakukan pencegahan terhadap penyakit Hipertensi.

Hasil penelitian menyatakan bahwa penyuluhan kesehatan sangat berpengaruh pada peningkatan pengetahuan responden. Hal ini menandakan bahwa dengan adanya pemberian penyuluhan kesehatan akan meningkatkan pengetahuan, perilaku seseorang dalam mengintervensi penyakitnya dengan mengontrol dan mencegah terjadinya kenaikan tekanan darah yang melebihi batas normal (Purwati, et.al.,2014).

Penelitian yang dilakukan Suparni (2010) berjudul Pengaruh penyuluhan terhadap pengetahuan dan sikap pasien tentang penyakit Hipertensi di Desa beton wilayah kerja puskesmas Siman kabupaten ponorogo didapatkan ada perubahan pengetahuan dan sikap tentang penyakit Hipertensi sebelum dan sesudah diberi penyuluhan di Desa beton wilayah kerja puskesmas Siman ponorogo.

Penelitian yang dilakukan Umah (2012) berjudul Pengaruh pendidikan kesehatan terhadap perilaku diet rendah garam pada pasien Hipertensi di Desa banjarsari RT 1 RW 01 manyar gresik didapatkan bahwa ada pengaruh pendidikan kesehatan terhadap perilaku (pengetahuan, sikap, tindakan) pada pasien hipertensi. Hasil penelitian diatas menunjukan bahwa penderita Hipertensi yang diberikan pendidikan dan pedoman dalam perawatan diri akan meningkatkan pola hidupnya yang dapat mengontrol tekanan darah dengan baik sekaligus mengingatkan bahwa pendidikan kesehatan akan lebih efektif bila petugas kesehatan mengenal tingkat pengetahuan perilaku dan kebiasaan seharihari klien tersebut.

Peningkatan pengetahuan pada responden merubah pola pikir responden sehingga mempengaruhi perilaku klien dalam menjaga kesehatan klien sehingga hasil akhir perubahan perilaku klien yaitu terjadinya penurunan tekanan darah baik diastol maupun sistol (Sulastri, 2018). Pada penelitian ini didapatkan perubahan sistol 
sebelum dan sesudah diberikan penyuluhan sebesar 17,3 untuk sistol dan 3,393 untuk diastol. Perubahan ini menunjukkan bahwa penyuluhan kesehatan efektif untuk menurunkan tekanan darah pada responden hipertensi.

Peningkatan pengetahuan melalui penyuluhan kesehatan berdampak terhadap perubahan sikap dan perilaku pasien hipertensi dalam memencegah terjadinya hipertensi berulang dengan pengendalian berat badan, pengurangan asupan natrium klorida, aktifitas, alkohol, pengendalian stress (Budisetio, 2011).

Penyuluhan kesehatan merupakan suatu cara merubah diri seseorang melalui informasai yang didapatkan untuk melakukan sesuai dengan yang diinginkan oleh yang memberikan penyuluhan (Budioro, 2012). Tujuan penyuluhan kesehatan untuk menambah pengetahuan responden. Dengan meningkatnya pengetahuan responden, maka ada perubahan sikap kearah adaptif sesuai dengan informasi yang didapatkan melalui penyuluhan kesehatan. Perubahan sikap akan mempengaruhi perilaku pola hidup sehat pada responden yaitu patuh untuk menjaga pola makan dan minum, aktifitas dan istirahat, pengendalian stress, dan patuh kontrol dan minum obat.

\section{Kesimpulan}

Karakteristik responden berdasarkan usia termasuk dalam lansia awal dan lansia akhir, dengan lama mengalami hipertensi lebih dari 5 tahun dengan IMT termasuk obesitas. Jenis kelamin mayoritas perempuan yang memiliki peluang lebih berisiko mengalami hipertensi dan tingkat pendidikan mayoritas rendah sehingga kurangnya pengetahuan dan pemahaman tentang penanganan hipertensi.

Penyuluhan kesehatan merupakan salah satu cara yang dapat meningkatkan pengetahuan sehingga berdampak pada perubahan pola hidup. Penelitian ini dapat disimpulkan bahwa terdapat perbedaan rata - rata kepatuhan pola hidup sebelum dan sesudah diberikan penyuluhan kesehatan, sehingga dapat dikatakan bahwa penyuluhan kesehatan efektif untuk meningkatkan kepatuhan pola hidup responden dengan hipertensi. 


\section{Ucapan Terimakasih}

Peneliti mengucapkan terimakasih kepada

Kemenristekdikti yang telah memberikan kesempatan dan dukungan dana dalam melakukan penelitian. Terimakasih kepada STIKes Mitra Keluarga yang telah memberi kesempatan kepada peneliti.

\section{Referensi}

Al-Saadi.R, et.all. (2016). Phenom about The silent killer by the life style. Alabama University: Disertasi : Not Pubished

Arief, 2008. Promosi Kesehatan. http://www.promosikesehatan.com/artikel.p hp.

Aryanto. (2014). Hubungan Tingkat Pendidikan Dan Dukungan Keluarga Dengan Kecemasan Pada Penderita Hipertensi. Diambil dari http://eprints.ums.ac.id/60156/25/NASKAH $\%$ 20PUBLIKASI\%20UPLOD\%20BENAR $\%$ 20BANGET.pdf

Batara, Bodhi, \& Kepel. (2016). Hubungan Obesitas Dengan Tekanan Darah Dan Aktivitas Fisik. Ebiomedik. Vol.4 no 1. Diambil dari https://ejournal.unsrat.ac.id/index.php/ebiom edik/article/view/10842

Budioro.(2012).Pengantar Pendidikan (Penyuluhan) Kesehatan Masyarakat, Edisi Revisi. Semarang : UNDIP

Budisetio. (2011). Pencegahan Dan Pengobatan Hipertensi Pada Penderita Usia Dewasa. Jurnal Univmed. Vol 20. No 2

Fodor J, G. H. (2009). Lifestyle Changes and Blood Pressure Control : A Community - Based Cross- Sectional Survey (2006 Ontario Survey on the Prevalence and Control of Hypertension), Jurnal FKM USU. Vol 11:31-35.

https://jurnal.usu.ac.id/index.php/kpkb/article/view/ 2085
Indriawaty \& Usman, S. (2018). Pemberdayaan Masyarakat sebagai Upaya Deteksi Dini Faktor Risiko Hipertensi. Jurnal Surya Masyarakat Vol.1,No.1: DOI: 10.26714

Kapti, et.al.,. (2013). Efektifitas Audiovisual Sebagai Media Penyuluhan Kesehatan Terhadap Peningkatan Pengetahuan Dan Sikap Ibu Dalam Tatalaksana Balita Dengan Diare Di Dua Rumah Sakit Kota Malang. Jurnal Ilmu Keperawatan UB. Vol 1 no 1. 53 - 59. Diambil dari: https://jik.ub.ac.id/index.php/jik

Kemenkes RI. (2018). Hasil UtamaRiskesdas 2018. Diambil dari http://www.depkes.go.id/resources/downloa d/infoterkini/materi_rakorpop_2018/Hasil\% 20Riskesdas\%202018.pdf

Khayyat, S. M. (2017). Predictors of Medication Adherence and Blood Pressure Control among Saudi Hypertensive Patients Attending Primary Care Clinics: A CrossSectional Study, 1-12

Kusuma, Kelana.(2016). Metodologi Penelitian Keperawatan : Panduan Melaksanakan dan Menerapkan Hasil Penelitian. Jakarta : Trans Info Medika

Lubis Zul Salasa, et.al.,. (2013). Pengaruh Penyuluhan Dengan Metode Ceramah Dan Diskusi Terhadap Peningkatan Pengetahuan Dan Sikap Anak Tentang PHBS . Jurnal FKM USU. Vol 2 no 3

Luknis, Sabri \& Sutanto Priyo Hastono. (2014). Statistik Kesehatan. Jakarta : Rajawali Pers

Mabuza, L. \&. (2015). A survey of risk factors associated with hypertension in the adult population of Kang, Kgalagadi North, Botswana, 177-182.

Marlina, Yessi, Emy Huryati \& Yati Sunarto. (2016). Indeks Massa Tubuh Dan Aktivitas Fisik Dengan Tekanan Darah Pada Pelajar SMA. Jurnal Gizi Klinik Indonesia. Vol 12.No.4.Diambil dari: jurnal.ugm.ac.id

Muamala. (2018). Kategori Umur menurut WHO dan Depkes. Diambil dari : 
https://muamala.net/kategori-umur-menurutwho/

Myung, Yang Hwa K. S. (2017). The Effect ofLifestyle Change on Blood Pressure Control among Hypertensive Patients. Korean Journal of Family Medicine; 38:173-18

Nawafleh, Kumara,et.al (2013). A descriptive study of adherence to lifestyle modification factors among hypertensive patients, Turkish Journal of Medical Sciences. Vol 1-23.

Ngatimin, 2003. Ilmu Perilaku Kesehatan Perubahan Perilaku Kesehatan. Makasar : FKM UNHAS

Novitanigtyas, Tri. (2014). Hubungan karakteristik dan aktifitas fisik dengan tekanan darah pada lansia di Kelurahan Makam Haji Kecamatan Kertasura Kabupaten Sukoharjo. Diambil dari http://eprints.ums.ac.id/29084/9/02._Naskah _Publikasi.pdf

Pratama, G.W. \& Ariastuti.(2016). Faktor - factor yang mempengaruhi kepatuhan pengobatan hipertensi pada lansia binaan Puskesmas Klunkung. Jurnal Medika Udayana. Vol. 5. Ritrieved fromDiambil dari https://ojs.unud.ac.id/index.php/eum/article/ view/19735

Pujasari, Ajeng, Setyawan \& Udiyono. (2015). Faktor - Faktor Internal Ketidakpatuhan Pengobatan Hipertensi Di Puskesmas Kedungmundu Kota Semarang. Jurnal Kesehatan Masyarakat. Vol. 3. No 3. Diambil dari http://ejournals1.undip.ac.id/index.php/jkm

Purwati, Riana, Hendro \& Abram Babakal. (2014). Pengaruh Penyuluhan Kesehatan Terhadap Pengetahuan Perilkau Klien Hipertensi Di Puskesmas Bahu Manado. Jurnal Keperawatan. Vol.2 no.2. Ritrieved from https://ejournal.unsrat.ac.id/index.php/jkp/ar ticle/view/5222

Sofyan, Elita \& Yusuf. (2015). Hubungan Umur, Jenis Kelamin dan hipertensi dengan kejadian stroke. Jurnal UHO. Vol 21 no 2 diambil dari http://ojs.uho.ac.id
Sucitaningtyas, Yundari. (2017). Hubungan Indeks Massa Tubuh Dengan Hipertensi Pada Penderita Penyakit Ginjal Kronik Di Rsud Dr. Moewardi Surakarta. E-journal Unsrat. Diambil dari http://ejournal.unsrat.ac.id

Sulastri. (2018). Pengaruh pendidikan kesehatan terhadap sikap dan perilaku personal hyegene gigi mulut anak SD di SD Negeri Payung. Jurnal Care. Vol 6 No 1. Diambil dari https://jurnal.unitri.ac.id >care>article

Suparni, 2010. Pengaruh Penyuluhan Terhadap Pengetahuan dan Sikap Pasien Tentang Penyakit Hipertensi. Diambil dari http://dglib.uns.ac.id/

Umah K, 2012. Pengaruh Pendidikan Kesehatan Terhadap Perilaku Diet Rendah Garam Pada Pasien Hipertensi.. Jurnal Unigres. Vol 8 No 2. Diambil dari http://jurnal.unigres.ac.id/

Wahyuningsih, Sri, Muttia \& Nurfitri Bustaman. (2018). Pengaruh Derajat Hipertensi, Lama Hipertensi Dan Hiperlipidemia Dengan Gangguan Jantung Dan Ginjal Pasien Hipertensi Di Posbindu Cisalak Pasar. Jurnal Kesmas Indonesia. Vol 10 no 1.

WHO.(2011). World Health Statistic 2011. Diambil Dari https://www.who.int/whosis/whostat/2011/e $\mathrm{n} /$

Widjaya,et.,al.,. (2018). Hubungan Usia Dengan Kejadian Hipertensi Di Kecamatan Kresek Dan Tegal Angus Kabupaten Tangerang. Jurnal Kedokteran Yarsi. Vol. 26 no 3; 131 138. Diambil dari: https://www.researchgate.net/publication/33 1781736_Hubungan_Usia_Dengan_Kejadia n_Hipertensi_di_Kecamatan_Kresek_dan_T egal_Angus_Kabupaten_Tangerang 